\title{
WHY WE NEED A WORLD DEVELOPMENT ORGANISATION
}

\author{
Ian Taylor
}

\begin{abstract}
Since the early 1980s a philosophical approach to economics and development, one that is broadly in alignment with the neoliberal mantra of liberalisation, privatisation and the "free market" has become hegemonic. Despite the evident intellectual bankruptcy of relying on "the market" for development and even after the post-2008 crisis, which exposed neoliberalism's failures, we have not witnessed any fundamental changes in most international institutions approaches to the most pressing issue of our time: sustainable development. This article seeks to demonstrate that a new organisation specifically aimed at promoting global development and free of the reformist discourses that pervade existing bodies (such as United Nations Conference on Trade and Development (UNCTAD)) is needed. Otherwise, debates will continue to be restricted to problem-solving issues, nothing will fundamentally change and global inequality (itself brought about by imperialism and neo-colonialism) will continue to characterise the global political economy.
\end{abstract}

Keywords: development, globalisation, neoliberalism, Gramsci

\section{INTRODUCTION}

"Development" and other terms such as "North-South", "First World-Third World", "developed world-developing world" etc. can be endlessly unpacked and debated. In this article, "development" refers to "the increasing capacity to make rational use of natural and human resources for social ends'. ${ }^{1}$ The term "the North" refers to the industrialised states e.g., the United States (U.S.), Europe, Japan etc., whilst "the South" refers to the underdeveloped countries, primarily located in the ex-colonial states of Africa, Asia and Latin America. Such states - in general - have faced immense development challenges and as the new century progresses and in the current neoliberal epoch, this continues. 
This article seeks to discuss some of the key developments that have occurred in the last few decades' vis-à-vis development thinking and relate such impulses to the overall globalisation moment. It is argued that since the early 1980s a philosophical approach to economics and development, one that is broadly in alignment with the neoliberal mantra of liberalisation, privatisation and the "free market" has become hegemonic. I use the term hegemonic in the Gramscian sense whereby the ideological, moral and cultural values of neoliberalism have become broadly accepted as "common sense" and largely unquestionable. ${ }^{2}$ Despite the evident intellectual bankruptcy of relying on "the market" for development and even after the post2008 crisis, which exposed neoliberalism's manifest failures; we have witnessed the 'strange non-death of neoliberalism'. ${ }^{3}$

Whilst we cannot overlook the coercive disciplinary aspect of the hegemony around existing economic models, in general the values and norms associated with neoliberalism have become largely accepted as the consensus, the starting point from which North-South dialogue now tends to base its foundations. Indeed, as this article seeks to demonstrate, the current reformist discourse, that seeks to ameliorate neoliberal globalisation with various ill-defined "developmental" ingredients, is essentially accepting of the common sense principles of neoliberalism and an "open" global economy. This has become the dominant elite position on the potentiality of development in the new millennium and illustrates the profound power that hegemonic neoliberalism possesses. There does indeed seem, from the perspective of elites in the South as well as the North, "no alternative". The inherent limitations, constraints and contradictions of this agenda and how current features associated with globalisation tend to undermine development are a key theme of this article.

At the same time, the opportunities that globalisation affords, particularly at the personal level will be mentioned, as will be the suggestion that what needs to be promoted, rather than the World Trade Organisation (WTO), is what we might term a World Development Organisation. A number of initiatives that might be considered for placing development at the centre of the world's concerns are advanced as part of this consideration. Essentially, it is argued that globalisation cannot be dismissed as an entirely negative phenomena; its technological advances have opened up a fair degree of agency 
for the South, even as other avenues for development appear to have narrowed and, it must be said, the intellectual discourse continues to be largely set by the North. The question is, how might identified opportunities be balanced with the negative and be directed at promoting broad-based development in the South?

\section{GLOBALISATION AND THE RECONFIGURATION OF POWER}

Globalisation itself is a term open to contention and it is vital to be specific as to what we mean, rather than talk in fairly meaningless terms of "space" and "time". ${ }^{4}$ Capitalism has always striven to be global and Marx's comments that the bourgeoisie 'compels all nations, on pain of extinction, to adopt the bourgeois mode of production; it compels them to introduce what it calls civilisation into their midst i.e. to become bourgeois themselves', remain as true today as when Marx wrote them. ${ }^{5}$ Indeed, the type, context and the essential impetus of the current process of capitalism associated with globalisation represent the universalization of capitalist social relations. ${ }^{6}$ Today, globalisation implies the making global of a host of social and economic factors which in aggregate terms further undermines distinctions between the international and domestic.

Integral to this process and something, which profoundly impacts upon the potentiality of development, is the on-going hegemony of neoliberalism. It is against this "standard" that all are judged and "development" itself must square with the familiar neoliberal package if it is to receive the stamp of approval from the important powers-thatbe within the global economy. Neoliberalism has, in the view of many, 'become the predominant ideology legitimating the privatisation of the state-controlled economy and the substitution of the market for the social provision of basic welfare'. ${ }^{7}$ How this might increase capacity to make rational use of one's natural and human resources for social ends is of course a moot and controversial point. Indeed, the privatisation of everyday life is increasingly problematic, not least in the realm of welfare provision, public goods or even, security. ${ }^{8}$

Of major importance is the scenario whereby "mono-economics", i.e. the belief that there exists a universal set of economic laws that apply across the board ${ }^{9}$ has emerged as a means of informing and 
shaping development practice. Although this has been systemic, the lead given by the Alan Greenspan (chairman of the U.S. Federal Reserve, 1987-2006) who promoted an ultraorthodox, free-market dogma based on the ideology of rational actors competing in open markets and reducing everything to mathematical models was vital.

The ideology of Homo economicus however is highly dubious if not dangerous if we are to advance a developmental agenda. Primarily, this is because, as Gray ${ }^{10}$ points out the dominant discourse surrounding neoliberalism 'represent [s] as inevitable what is, in fact, a highly unlikely outcome of the current drive to create a free market...[Conflating]...the end-state favoured by the project with the actual development of economic globalisation... [They] represent... an historical transformation that has no end-state and which is subverting American capitalism as well as its rivals, as a process leading to a universal acceptance of American free markets'. If the dominant development model (informed by American-style capitalism) is so blissfully ignorant of all other experiences, whilst projecting hyperliberalism as a universal, then development that is culturally sensitive and specific to the differences that exist across the globe is certainly under serious attack. Indeed, if development is about the ability to make sensible use of resources in the service of society then we are all in trouble. As Cox remarks: ${ }^{11}$

In America, which is the model for globalisation, a thriving economy has in recent years generated both a high level of employment, much of in low-paid and precarious jobs, and a growing polarisation of incomes. There are signs that rampant individualism may have passed a point at which it serves as a dynamic of economic competition to become a threat to social cohesion.

Very few people would agree that the American economic model is a rational developmental plan for long-term growth and empowerment.

Intimately linked to the above are the dynamic of social relations and the reconfiguration and intensification of social (or dare we say it, class) struggles. Thus we can say that globalisation is primarily about the reconfiguration of power on a global scale with a profound 
influence over epoch-making changes vis-à-vis economic, social, gender, and financial and political relations. These shifts, generated by the impulses associated with the global-wide diffusion of capital's power, makes any discussion of development problematic, even though there are some opportunities that exist within this broader framework (see below). Why development has reached a crisis point in today's world is intimately linked to the last half century or so and the history of "Development" as a discipline, something which needs briefly discussing.

\section{LOCATING DEVELOPMENT}

Modern debates regarding development emerged from the maelstrom of the Second World War, for it was in this post-war period that the developing world began to "fit" into the wider international political economy in a way that had not been readily apparent in the pre-Cold War era. The developing world was rapidly configured in a series of often overlapping layers of spheres of economic and political influence, which were continuations or developments from the colonial period. That this was intimately linked to the Cold War is quite apparent: Latin America remained under U.S. tutelage, with American-based transnational capital continuing to dominate the economic life of the continent. This was an actuality that required defending at all costs, particularly in the post-Castroist era, hence the "Alliance for Progress" in the 1960s. East and Southeast Asia, after massive amounts of American capital were poured into the region post-Korean War was largely under the "direction" of a revived Japanese capitalist class. This class, in effect acting as a proxy for Washington, sought to reconfigure the region as a site of investment and a particular form of state-led growth.

The rise of the "Asian Tigers" complimented this process and indeed, in many cases was driven by the demand to bolster a capitalist-oriented (read: anti-Communist) barrier to the further spread of socialism. The desire to protect this scheme of things was one of the fundamental reasons for Washington's (ultimately disastrous) involvement in Indo-China. Finally, Africa was left to the metropolitan powers and their transnational (or in semi-periphery states such as Portugal, national) corporations to continue "business as usual", though cognisance was made, increasingly at the point of an insurgent's 
bayonet, that a re-thinking on Euro-African relations was imminent and long overdue.

As ever, the South's development post-1945 was in essence a micro-process within a broader macro-process. This broader milieu was the post-war economic-political settlement, the "embedded liberalism" of the Bretton Woods institutes (BWI) and its sister groups, namely the World Bank, the International Monetary Fund (IMF), and the General Agreement on Tariffs and Trade or GATT (now the WTO). ${ }^{12}$ This was in essence a post-war "Golden Age", a compromise between capital and labour via various Keynesian welfare nationalist schemes. Under the aegis of the Bretton Woods institutions, "mixed economies" and a liberalising international economy became central to this arrangement. This settlement stimulated the development of economic-political agents: externally oriented transnational corporations, national (inwardly-looking) monopolistic/oligopolistic corporations, and state administrations. ${ }^{13}$ These agents created in both the North and, to a lesser degree the South, "triple alliances" which overlooked the economic and political evolution of both.

Having said that, this occurred at an historic juncture when the newly independent nations of the South were flexing their muscles and there was a heady optimism regarding the manoeuvrability of the developing world vis-à-vis the North. Indeed, some writers, asserting that dependent relations constructed during the colonial period precluded development within the wider world economy advocated an auto centric "de-linking" from the capitalist world economy. ${ }^{14}$ This did not imply an autarkic utopia, but rather a development strategy that emphasised domestic requirements over excessive reliance on external demand. A return to this agenda continues to be a prerequisite for genuine sustainable development.

\section{GLOBALISATION AND THE HISTORIC RETREAT OF THE SOUTH}

However, the South's efforts to put forward a New International Economic Order (NIEO) in the 1970s which would radically recast global economic relations was not to last long and has now virtually disappeared. The reassertion over the South of Northern politicoeconomic dominance came at a historical juncture when financial 
indebtedness was acting to drastically undermine (if not emasculate) sovereignty and manoeuvrability in the South. Since formal independence, the South has, because of its dependent relationship on the North, continually borrowed from the industrialised world to nurture their economies. With the recycling of petro-dollars making borrowing an easy option, most of the South indulged in massive borrowing with their external debt expanding at a very rapid and unsustainable rate. The concomitant reckless adventurist lending practices of the North's bankers contributed to this process. The massive debts created immense problems for the South, with such debts creating a vicious Catch-22 situation whereby funds to finance development were diverted to pay off debts. In addition, the necessity to secure foreign currencies to service the debts led to a quick depreciation of many Southern currencies and hyperinflation. Paradoxically, oil prices, which had initially stimulated the lending/ borrowing spree, exacerbated the problem.

At the same time, leadership fractions within the South were increasingly drawn into the on-going restructuring process as promoted by neoliberalism. Indeed, the call for liberalisation - dressed up as it was in the rhetoric of economic "realities" - gave space for conservative elements within the ruling elites of the South, who had always been reluctant to concretely commit themselves to the NIEO. Their seizure upon the growing globalisation discourse to help explain away unpopular policies to cope with the debt crises reflected a longstanding minimal commitment to any major restructuring of the global economy (except where it benefited Southern elites). This, combined with an ever-increasing hegemonic consensus amongst elites over the liberalisation of economic policies, meant that "alternative" visions regarding the international political economy were conceived as largely redundant among elite circles. Confrontationist expressions, which had been omnipresent in much of the South's rhetoric in the 1960s and 1970s, were now deemed incongruous in a world where there was "no alternative" to neoliberalism.

As the debt crisis worsened in the South, growth stagnated, employment declined, monetary arrangements collapsed and financial agreements between creditors and debtors were increasingly undermined by mass bankruptcies. With the demise of the Cold War (a process that had begun with Mikhail Gorbachev's standing down 
of Soviet adventurism abroad in the 1980s), options emanating from the East appeared to evaporate. In short the room for manoeuvre by Southern elites became more and more constricted. ${ }^{15}$ The means to overcome the crisis in development thinking was with a resort to borrowing from two old theoretical approaches: neo-classical economics, and Modernisation Theory. ${ }^{16}$ This combination was part and parcel of the structural adjustment programmes (SAPs) that reconfigured whole swathes of the developing world in the 1980s. Within SAPs was an implicit echoing of the modernisers' argument that the "fundamentals" had to be in place to assure economic development. Failure to do this, particularly by African states, was blamed for the failure of SAPs in many countries. ${ }^{17}$

It was in this context that the state elites within Southerndominated development-oriented bodies such as the United Nations Conference on Trade and Development (UNCTAD) and the NonAligned Movement (NAM) sought to re-package their organisations. Certainly, whilst the logic of neoliberalism was broadly accepted by most, the negative effects of globalisation were equally felt. An acceptance of the normative principles of neoliberalism, whilst advocating ameliorating policies to cope with this "actuality" emerged as defining principles upon which the two organisations began to operate and how "development" might be re-thought in the context of globalisation. This process gathered pace as the demise of the Cold War became apparent. At the ninth summit of the NAM in Belgrade in 1989, Yugoslavia 'pleaded for the modernisation of the Movement [thus] discarding the NAM's attitude of assertiveness vis-à-vis the two power blocs. Instead, the NAM [adopted] a more tolerant and flexible position with emphasis on co-operation and dialogue'. ${ }^{18}$ The next Summit in Indonesia in 1992 produced the Jakarta Declaration, which many saw as 'the first major reaction of the NAM to the emerging world order'. ${ }^{19}$ Post-Jakarta the NAM changed its approach and orientation from one that was often viewed as confrontational to one that was conciliatory and co-operative. This process was also exhibited at UNCTAD VIII in Cartagena, Colombia in 1992 where the "Spirit of Cartagena" recognised the central roles of private enterprise and the market for growth, and recognised the 'shared responsibility and partnership for development' (The Spirit of Cartagena). ${ }^{20}$ 
This "Spirit" reflected an essential acceptance of neoliberalism, with the abandonment of any confrontational posturing in the final communiqué. Instead, there was talk of the need to overcome confrontation and to foster a climate of genuine co-operation and solidarity in order to facilitate development. The Cartagena Summit of the NAM, held in October 1995, continued the broad trajectory that Jakarta had exemplified. For sure, the "Call from Cartagena", whilst containing many of the old familiar non-aligned themes such as sovereignty, disarmament and anti-colonialism, also contained within it a commitment to "sound macro-economic management" and growth as a precursor to development. This reflected what Mittelman and Pasha described as the underpinnings of international organisations in the globalisation era: ${ }^{21}$

Changes in global production and politics are reflected in the ideology of international organisations. They disseminate values and norms that contribute toward redesigning the global political economy. From the height of the Cold War to the more recent concerns of globalisation, international institutions have absorbed the realities of global political economy and its contradictions. Imbued with neoliberal doctrines, the current remedy for all ills is the market.

That this was broadly so with the NAM, was shown by Cartagena's demand for a better working relationship with the World Bank, IMF and the WTO. This wish to further increase the dialogue between the disciplinary institutions of neoliberalism and erstwhile development institutions was to remain a feature of both the NAM's and UNCTAD's position. Such actualities reflected a playing out of the increasing integration of the world's markets and the desire by local Southern-based elites to benefit from this process wherever possible. Combative posturing against the structural inequalities of the capitalist system, characteristic of the dependenista position, were seen to be of little use in facing up to globalisation, particularly when - as has been pointed out - much of the elites in the South subscribed to neoliberalism. Even those that did not fully accede to this "New World Order" were painfully aware of the on-going marginalisation 
that much of the South was enduring. It was in this context that, with the exception of Cuba and North Korea, no state elites openly rejected the ideology of neoliberalism as the "correct" path to development.

\section{DEVELOPMENT AND DEMOCRACY: THE MISSING LINK UNDER GLOBALISATION}

In this light, state administrations in the developing world are held hostage to a Janus-faced dilemma with regard to the pursuit of development. On the one hand they are now supposedly beholden to their (increasingly dissatisfied) domestic constituencies whilst on the other, and probably much more so, they are accountable to unelected external creditors and donors. ${ }^{22}$ This has resulted in the creation of highly fragile "democracies", which remain unable to satisfy the demands and aspirations of the poor majority whilst socio-economic improvements and development plays second fiddle to the increasingly strident requirements of the IFIs and donors, with everything wrapped up within the "no alternative" thesis associated with specific readings of globalisation. This reality stakes out whole swathes of the global South at present, stimulating uncertainty and instability throughout the developing world.

In the light of shifting definitions of what constitutes development we can say that this very powerful term is evidently a historically contingent form of knowledge, closely tied to dominant structures and global power relations. It is not some sort of ahistorical set of universally applicable goals. The type of neoliberal precepts that underpin the contemporary development discourse associated with good governance and particular notions of democracy helps contribute to a continuation of a profoundly undemocratic world order, despite the claims made by its promoters. Much of this is wrapped up in excited talk regarding the supposed "global village" we all live in. However, Klein ${ }^{23}$ excellently captures what this village means for many in respect of development and empowerment:

This is a village where some multinational, far from levelling the global playing field with jobs and technology for all, are in the process of mining the planet's poorest back country for unimaginable profits ... IBM claims that 
its technology spans the globe, and so it does, but often its international presence takes the form of cheap Third World labour producing the computer chips and power sources that drive our machines. On the outskirts of Manila, for instance, I met a seventeen-year-old girl who assembles CD-ROM drives for IBM. I told her I was impressed that someone so young could do such high-tech work. "We make computers", she told me, "but we don't know how to operate computers". Ours, it would seem, is not such a small planet after all.

Having said this, the reductionist tendency to see globalisation as simply a manufactured conspiracy emanating from the North must be avoided: 'by a project [we] don't mean (as Gramsci warned) a conspiracy. [We] mean the construction of a new agenda, the constitution of a new force'. ${ }^{24}$ Indeed, the process is more accurately a 'complex convergence of interests among an increasingly cohesive transnational elite headed by a U.S.-led Northern bloc' but also 'incorporating elite constituencies in the South'. ${ }^{25}$ This process has tended to frustrate the developmental demands and aspirations of people of the South. This has gone hand in hand with the rise of powerful rhetoric surrounding democratic norms, but which are highly constrained and largely procedural in nature. Indeed, 'the framing and circumscribing of democratic thought and discourse in terms of the precepts of polyarchy can be understood as an effort by core state elites to solidify and stabilise the hegemony which safeguards their positions of power and privilege' within the global economy. ${ }^{26}$ By doing so the current politico-economic arrangements are legitimised - after all, suffrage has been universalised and hence grievances are remedied via the ballot box, not mass action/revolution or self-development: ${ }^{27}$

[T]he combination of economic and political liberalism [in polyarchy] is...not democracy per se...but that is not the point; the point is that the dominant discourse has determined that it is. And of course economic liberalism is but another term for capitalism, so that capitalism appears as the economic face of democracy, thus downplaying the negative associations, in the South, between capitalism 
and imperialism and collapsing the elite ideological construct into [an] amorphous but demagogically effective concept of democracy.

When George W. Bush advanced the idea that the war in Iraq was a precursor to a broader crusade for democracy in the Middle East, this was always tied in with the promotion of "free markets". Yet such an agenda would almost certainly not be interested in the democratisation of the economies of the Middle East i.e. transferring ownership of the oilfields of the Gulf from the oil companies and local elites, to the people. That would be one step too far for the powers-that-be. Rather better to intimately connect democratisation to the "opening up" of the economies of the region. Who would benefit from such a process is of course a moot point.

\section{GLOBALISATION AND DEVELOPMENT: A FREE $A N D$ FAIR INTERNATIONAL SYSTEM?}

The abovementioned scenario currently marks the contemporary period, where neoliberalism remains the hegemonic ideology vis-àvis economic organisation and where a restricted form of democracy serves to legitimise this order. Having said that, there has begun to emerge a nascent call for a more inclusive form of globalisation. This is still very much at an embryonic stage, but it seems that there is gathering momentum for some reformist impulses. This movement is in essence a synthesis of Modernisation Theory-inspired precepts associated with neoliberal adjustment programmes and what constitutes "good governance", but which equally asserts that the world order is currently heavily weighted in favour of the North and needs redressing, a position that links up (though its advocates would never admit it!) with the insights of Dependency Theory.

Indeed, concern has increasingly been expressed that the historic bargain by the South to drop its confrontational posture in return for benefiting from globalisation has been a largely one-sided affair as development has stagnated in large parts of the globe or only benefitted the few. Certainly, how organisations such as UNCTAD's developmental remit relate to the WTO has emerged as a site of concern for the South. This is particularly as the North has opposed any reference to the implementation of 'specific WTO agreements, 
especially if developing countries suggested that their developed counterparts were not honouring their obligations' ${ }^{28}$

From this emerging perspective, the WTO is seen by many elites in the South as having strengthened the rules-based trading system, furthering liberalisation and opening up opportunities for sustainable development and growth. Confrontation with the North has now given way to "dialogue", yet as this more "toned down" message from the South emerges, it is apparent that with the acceptance of the hegemonic norms of trade liberalisation and the implicit acceptance of the modernisation project goes a recognition of the uneven process of globalisation. This has translated itself into a position that has called for a lessening of the worst aspects of this process.

It is this urgency to expose the hypocrisy of the North in its calculated push for free trade in the South - whilst keeping various segments of its own markets closed to Southern competition - that impels elements in the South to engage with the North. Many Southern elites now accept the call for neoliberalism restructuring, but turn this rhetoric around and urge the North to engage in supposed real free trade, rather than the "actually existing free trade" situation currently marking international commerce and which frustrates many developmental ambitions. This urge for a critical engagement with the North tends to be characterised as "partnerships", which attempts to deal with both positive and negative aspects of the on-going globalising process.

Though at a basic level elites in the South have embraced neoliberalism (with all its negative implications for sustainable development), they do seem aware of the negative downsides and pressures that are concurrent with globalisation. Thus leading elements within the South promote a reformist agenda aiming to "improve" the global system whilst promoting a more rules-based international regime. Southern engagement with what is perceived as the unstoppable juggernaut of globalisation strives to match the rhetoric of liberalisation with its universal application. Thus recent calls for "partnership" are predicated upon this free trade framework and aims to move towards some form of workable relationship with the North in order to lessen the more negative aspects associated with globalization. 
At the same time, there seems to be a broad agreement that the out-and-out opening of their economies as demanded by the North is flawed as long as the North maintains barriers to trade and, moving beyond the purely economic, a realisation that globalisation has profound cultural and social implications, not least in the South. According to this viewpoint, the cultural and social specificities of change need to be intricately accounted for and accommodated. Various impulses in parts of the South have expressed resentment to the totalising effects of essentially Western-driven globalisation and the impact such processes are having on the cultural bases of societies in the South. After all, leaders such as Mahathir Mohamed of Malaysia expressed themselves quite forcefully within the context of "Asian values" whilst Subcomandante Marcos of the Chiapas frequently couched his anti-globalisation rhetoric in terms of the defence of indigenous culture and society in the face of an omnipotent global tidal wave.

However, the viability of this call for a new world order, which explicitly aims to promote development within the context of a globalising world market, remains open to question. Indeed, whilst the history of North-South relations, with its concomitant struggle between the precepts of Modernisation Theory and Dependency Theory, may well now be turning, whether this new turn in development thinking is sustainable needs interrogation. Is it actually possible to deregulate markets and roll back the state, allowing a free rein for international capital and, at the same time promote equity and mutual development in both North and South? What does it actually mean to call for development couched in cultural terms, when the model being advanced is basically one from the Western core? Surely such calls are contradictory and may in fact reflect the phenomena of "talking left, but acting right". Those advocating such a turn need to answer a most fundamental problem: is it intrinsic to the capitalist system that the generation of wealth is predicated upon poverty-producing principles? Must there always be a dominant sector in society and a dominated sector in society - in international terms, a North and a South? Is the call for a new development partnership a chimera, or is it attainable? Finally, does global capitalism necessarily undermine and transform "tradition" and "culture" in ways that may be unforeseen, even uncontrollable? Whilst defensive gestures regarding the impact of globalisation on society may be detected in initiatives from the 
South, the reality of how dominant neoliberal ideas have become seems to militate against specifically regional responses. Thus whilst there seems to be a recognition of the perils of willy-nilly opening up to globalism and how this might impact upon the economic, cultural and social well-being of territories in the South, the response so far appears to be confused and paradoxical.

Yet at the same time globalisation brings opportunities and agency. Improved technologies and greater interaction between peoples can be empowering and uplifting. Virtual solidarity across the internet cannot be waved away as irrelevant and lessons from other parts of the South on strategies to cope with - and perhaps transform - impulses associated with globalisation can be disseminated at a speed previously unthinkable. Indeed, the new global media has established potent networks providing a powerful means of advancing and projecting local cultures to the rest of the world. And of course, opponents of globalisation use the technology associated with the "global village" to disseminate their opposition. In addition, the movement of peoples across borders has accelerated in the era of globalisation. Over the years, many people from the South have moved North. Whilst this has been primarily for economic reasons, the existence of new diasporic networks provides the South with opportunities that may help stimulate some development, even if only at the grassroots level. After all, remittances from expatriate workers have created a regular flow of foreign capital back to the South that may be invested productively in the home countries. In addition, diasporas develop contacts and skills that may open up new experiences and exposure to the most recent technological innovations; again, to be possibly used back home. These diasporas, a potent symbol of globalisation, can make a contribution to promoting development in the South and should not be seen simply as the evacuation of talent and skills from the South to the North with little or no benefit to the developing world.

Thus we can say that a negative dichotomy between all aspects of globalisation and development - however defined - cannot be assumed. Whilst the neoliberal aspects of globalisation are profoundly questionable, especially the reification of the "free market", other elements associated with globalisation such as intensified communication, human interaction and improved access to such technologies can have positive developmental spin-offs. The question 
is, how is globalisation managed and how can its positive aspects be directed towards development so as to maximise its benefits? In essence, whilst globalisation is mostly about the reconfiguration of power on a global scale, it is also about epoch-making changes regarding economic as well as social, gender, and cultural relations. These changes provide opportunities for developmental thinking as well as problems and barriers. In this sense, the notion and potentiality of "development" should not be seen as closed off under the conditions of globalisation, but rather demands a rethinking of what exactly it constitutes in the modern era. Much of the pessimistic readings regarding globalisation may after all, be simply failures in the imagination.

\section{BEYOND GLOBALISED "PARTNERSHIPS" AND TOWARDS A WORLD DEVELOPMENT ORGANISATION?}

Asserting that the developing world must basically "get with the programme" of neoliberalism, without interrogating the global structural situation - and coming up with concrete proposals on how to restructure them - is highly problematic in the long run. How can the developing world protect its own cultural values and societal norms when "the programme" is essentially a one-size-fits-all framework with very little cognisance (or time) for cultural nuances and difference, or for development? Issues surrounding the continued thrust and direction of globalisation need to be taken seriously in the global power centres.

Thus far, the "partnerships" being promoted between North and South have been predicated on the belief that "development" will inexorably follow trade and growth. However, this discourse falls short in providing an alternative to the hegemonic market logic of neoliberalism and runs the risk that the reformist impulses currently being observed from the South treads a path whereby they may well end becoming the disciplining spokesman of global economic forces. There is the danger that if left unchecked the state in the South (or what is left of it) may become a 'transmission belt' for economic globalisation, rather than a mediating influence seeking to craft beneficial partnerships that promote development.

Although a great deal of emphasis is placed on the phenomenon of "globalisation", the absence of any sustained structural analysis of current global interactions is also evident in the failure to interrogate 
the structural effects that globalisation, driven by the liberalisation of the markets for goods, ideas and capital, has had on the very nature of the state and indeed, development itself. Any alternative vision regarding global development might be expected to fundamentally interrogate the inequitable global trading system and re-think aspects of its rules-based regime so as to benefit the least developed. A thorough overhaul of the international financial system is a prerequisite if the South is to even begin pursuing development. After all, in a world characterised by footloose capital, it is nigh on impossible to acquire any capacity to make rational long-term use of one's resources for developmental ends. In addition, the North needs to re-evaluate, with their Southern trade partners, the issue of market access and tariffs. This is because the thus far dominant debate on tariffs misses an important point.

First of all, non-tariff barriers to trade are extremely important and act as a barrier to market access to Southern exporters. Of course, issues such as sanitary and phyto-sanitary measures, accurate labelling and product details are important. However, in the past not only have such regulations acted to prevent the trade of products from the South due to the failure to meet such standards, but also it has become quite apparent that developed economies have often resorted to using concerns over standards as a form of protectionism. Secondly, however, and perhaps the major barrier preventing the South trading with the North on a level playing field is the issue of subsidies, particularly in agriculture. It is in agricultural products that the South often has a distinct comparative advantage, but it is in this sector that the North so assiduously prevents market access through the use of subsidies to domestic producers. The outrageous subsidies for agricultural producers in the North would need to be addressed as such structures effectively close off the North's markets to Southern exports and hence obstruct rural poverty alleviation strategies. After all, what kind of global system is it that permits a cow in Europe to receive nearly two and a half dollars a day whilst over half of Africans have to live on less? Any development plans that even pretend to want to support agriculture in the South and help alleviate rural poverty has to directly target the subsidies in the West.

What is being argued is that the dominant line on how development might be "factored in" to globalisation, but which 
neglects major structural issues in the global economy, is likely to be counter-productive. It is simply not good enough to predicate such calls around "growth" and hope that development will somehow occur. In this light, the current debate between the North and the South is likely to fail to address developmental aspirations as it fails to advance any concrete agenda regarding the asymmetric power relations between the two. It is this inequality that is a significant cause of maldevelopment and a huge hurdle for any developmental project to get off the ground. In this sense, globalisation as understood as the reconfiguration of power on a global scale is clearly having a profound impact upon the developmental opportunities of the South. In particular, the hypocritical and one-sided nature of liberalisation associated with globalisation is highly problematic. In addition, any world organisation that seeks to advance a universalistic message ("free markets for all") without acknowledging the profoundly different levels of development across the globe is profoundly amiss. Even if market access is granted to the South at favourable terms and even if all subsidises are removed, the differential levels of productive capacity, supply ability, marketing expertise etc. may well undermine any potential gains. Producers in the South are disadvantaged from the start, before they even begin to export their products and so a truly development-oriented body, rather than one that fetishes "trade", would have to address such issues.

What is needed is a new agenda that places development at the centre of globalisation as it pertains to trade, rather than the other way around. The demand by the neoliberal globalisers to open up willy-nilly to "international trade" without taking too much cognisance of the developmental implications that this may have is problematic, to say the least. Trade and commerce needs to be placed at the service of what the South most desperately needs (development) rather than reifying "trade" as the be-all and end-all. Rather than having a global order based on a world trading system that seeks to maximise international trade and avenues for foreign investment, what is needed is to convert the WTO into the WDO - the World Development Organisation. Such a body would be far more sensitive to the needs of the South and what sort of global system would promote the ability of developing countries to advance their own unique and different developmental goals.

Indeed, a WDO would abandon the one-size-fits-all framework that neoliberal globalists promotes and would rather accept diversity in 
the way in which territories organise themselves and regulate economic practice. This would require the abandonment of the neoliberal mantra of "no alternative" and the acceptance that such universalistic discourses have proven to be counter-productive to the South. It is surely axiomatic that economies at different levels of development have different requirements when it comes to regulation and social values. After all, there are qualitative differences between Northern Europe's social corporatism and Thatcherism; between Asia's diverse communitarianism and hyper-liberalism; and between South Europe's co-operative ventures and the ruthless "free market". Any economic historian would admit that policies that spurred development in the North were not based on neoliberal ideas, which fetishized the market beyond all - quite the opposite. In fact, all late industrialisers, as well as earlier ones, deployed various forms of economic nationalism and protected themselves. This is the total opposite of what the oneworld neoliberal globalists assure is the way forward to growth and development. Currently, the imposition of such ideas on countries at a vastly different level of development has seen the erosion of what developmental gains had already been attained and smacks of a cynical hypocrisy, particularly when such promoters do not even follow through with their own rhetoric when it comes to their own markets.

A WDO would allow countries to maintain national differences in areas where it was felt that the intrusion of international competitors would erode or destroy local activities that have broad backing. Thus the demand for simply opening upon one's economy to international competition, with little regard for the social consequences, would be replaced by a more nuanced acceptance and understanding that if such practices would run counter to the developmental or social aspirations of the populace, then caution and restraint could be exercised. Such a code would acknowledge the need to safeguard the developmental rights of the people rather than the "rights" of transnational corporations.

As it stands, such a WDO appears some distance off, to say the least. Pessimism of the intellect, optimism of the will must be admitted as per Gramsci. Surely, as long as Southern elites remain beholden to the overarching influence of hegemonic neoliberalism and the globalisation discourse of "no alternative", the paucity of new ideas regarding development and global transformation remain 
wedded to an inherently limited and short-termist vision of reform. However, whilst this is unlikely to fundamentally question (as is required) the current economic and political relations that characterises our grossly unequal world, we $d o$ need alternative thinking regarding how development may be encouraged and promoted by globalisation. It is becoming increasingly obvious that most creative thinking regarding alternatives to the current world order and its various negative manifestations comes from the bottom-up, rather than from the (largely) unimaginative state elites and their corporate allies. It has mostly been non-governmental organisations, often working in partnership with the state and/or companies, which have advanced incredibly important agendas relating to a whole spectrum of issues and topics. Opportunities to promote a better world do exist and agency has not been completely eradicated.

Whilst such campaigns may be dismissed as mere problemsolving activities, they have improved people's day-to-day lives and "global civil society" 29 is now a reality, often using the opportunities provided by the Internet and improved communications technology. These think tanks and advocacy networks are likely to play an increasing role in promoting developmental issues in the future. The question that will most likely dominate debates in the first decades of the millennium is, perhaps, how do we link daily struggles of resistance and change to tackling the much broader issue of resolving the crisis of development under conditions of hegemonic neoliberalism? This task, to move forward to making development at the centre of any talk regarding globalisation, is perhaps the most urgent mission humanity faces today.

\section{NOTES}

1 James Mittelman and Kemal Mustapha Pasha, Out From Underdevelopment Revisited: Changing Global Structures and the Remaking of World Order, Basingstoke: Macmillan, 1997, p. 25.

2 Mark Rupert, Ideologies of Globalization: Contending Visions of a New World Order, London: Routledge, 2000.

3 Colin Crouch, The Strange Non-Death of Neoliberalism, Cambridge: Polity Press, 2011.

4 Justin Rosenberg, The Follies of Globalisation Theory, London: Verso, 2000. 
5 Karl Marx and Friedrich Engels, The Communist Manifesto, Moscow: Progress Publishers, 1971.

6 Ellen Meiksins Wood, "Global Capital, National States," in Mark Rupert and Hazel Smith (eds.), Historical Materialism and Globalization, London: Routledge, 2003, pp. 17-39.

7 Henk Overbeek and Kees van der Pijl, "Restructuring Capital and Restructuring Hegemony: Neo-Liberalism and the Unmaking of the PostWar Order," in Henk Overbeek (ed.), Restructuring Hegemony in the Global Political Economy, London: Routledge, 1993, p. 1.

8 Bernadette Muthien and Ian Taylor, "The Return of the Dogs of War?: The Privatisation of Security in Africa," in Thomas Biersteker and Rodney Bruce Hall (eds.), The Emergence of Private Authority in Global Governance, Cambridge: Cambridge University Press, 2002, pp. 183-202.

9 Albert Hirschman, Essays in Trespassing: Economics to Politics and Beyond, Cambridge: Cambridge University Press, 1981.

10 John Gray, False Dawn: The Delusions of Global Capitalism, London: Granta Books, 1998, p. 3.

11 Robert Cox, The Political Economy of a Plural World: Critical Reflections on Morals and Civilisation, London: Routledge, 2002, p. 180.

12 Eric Helleiner, States and the Re-emergence of Global Finance: From Bretton Woods to the 1990s, Ithaca: Cornell University Press, 1994.

13 Kees van der Pijl, The Making of an Atlantic Ruling Class, London: Verso, 1984.

14 Samir Amin, Delinking: Towards a Polycentric World, London: Zed Books, 1985.

15 I. M. D. Little, Richard Cooper, Max Corden and Shrivath Rajapatirana, Boom, Crisis, and Adjustment: The Macroeconomic Experience of Developing Countries, Oxford: Oxford University Press, 1994.

16 Robert Lensink, Structural Adjustment in Sub-Saharan Africa, London: Longman, 1996.

17 Charles Harvey (ed.), Constraints on the Success of Structural Adjustment Programmes in Africa, London: Macmillan, 1996.

18 J. J. G. Syatauw, "The Non-Aligned Movement at the Crossroads: The Jakarta Summit Adapting to the Post-Cold War Era," Asian Yearbook of International Affairs, No. 3, 1993, p. 129.

19 Amadu Sesay, "Africa, Non-Alignment and the End of the Cold War," in Sola Akinrinade and Amadu Sesay (eds.), Africa in the Post-Cold War International System, London: Pinter, 1998, pp. 147-171. 
20 'The Spirit of Cartagena', declaration adopted by UNCTAD at its eighth session held at the Convention Centre, Cartagena de Indias, Colombia, from 8 to 25 February 1992, <http://www.inro.com.my/inro/cartagena.htm>

21 Mittelman and Pasha, Out From Underdevelopment Revisited, p. 25.

22 Rita Abrahamsen, Disciplining Democracy: Development Discourse and Good Governance in Africa, London: Zed Books, 2000.

23 Naomi Klein, The Shock Doctrine: The Rise of Disaster Capitalism, London: Allen Lane, 2001, p. xvii.

24 Stuart Hall, Thatcherism and the Crisis of the Left: The Hard Road to Renewal, London: Verso Press, 1990, p. 163.

25 William I. Robinson, "Pushing Polyarchy: The U.S.-Cuba Case and the Third World," Third World Quarterly, Vol. 16, No. 4, 1995, p. 653.

26 M. Neufeld, "Globalization: Five Theses," paper presented at the conference Globalization and Problems of Development, Havana, Cuba, January 1999.

27 William Graf, "Democratisation "for" the Third World: Critique of a Hegemonic Project," Canadian Journal of Development Studies, Special Issue, 1996, p. 44.

28 Xavier Carim, South Africa and UNCTAD IX: New Beginnings? Pretoria: Institute of Strategic Studies, Occasional Paper No. 7, August 1996, p. 3.

29 Martin Galsius, Mary Kaldor and Helmut Anheier (eds.), Global Civil Society 2002, Oxford University Press: Oxford, 2002. 